\title{
CONTROL METHOD IN COGNITIVE MAPS BASED ON WEIGHTS INCREMENTS
}

\author{
V.D. Romanenko, Y.L. Milyavsky \\ Educational and Scientific Complex "Institute for Applied Systems Analysis" \\ of National Technical University of Ukraine "Kyiv Polytechnic Institute"
}

Когнитивные карты широко используются для моделирования сложноструктурированных многомерных систем разной природы. Особой важностью обладает вопрос управления динамикой импульсного процесса в системе, описываемой когнитивной картой. Целью данной работы является разработка и исследование такого метода управления, который использует приращения весовых коэффициентов ребер когнитивной карты в качестве управляющих воздействий. В статье предложена модель управляемого импульсного процесса для этого случая, а также критерий оптимальности для формирования управления. Выведен закон управления и исследована устойчивость замкнутой системы. Алгоритм промоделирован на примере когнитивной карты социальноучебного процесса студента. Результаты разработанного метода подтверждают возможность эффективного перевода вершин когнитивной карты на новые уровни.

Ключевые слова: когнитивная карта, закон управления, приращения весовых коэффициентов, стабилизация на новых уровнях.

Когнітивні карти широко використовуються для моделювання складноструктурованих багатовимірних систем різної природи.Метою даної роботи є розробка і дослідження методу управління імпульсним процесом когнітивної карти, що використовує прирости вагових коефіцієнтів ребер в якості керуючих впливів. У статті запропоновано модель керованого імпульсного процесу для цього випадку, а також критерій оптимальності для формування управління. Виведено закон керування та досліджено стійкість замкненої системи. Алгоритм змодельовано на прикладі когнітивної карти соціальнонавчального процесу студента. Результати розробленого методу підтверджують можливість ефективного переводу вершин когнітивної карти на нові рівні.

Ключові слова: когнітивна карта, закон керування, прирости вагових коефіцієнтів, стабілізація на нових рівнях.

\section{INTRODUCTION}

Cognitive map (CM) is an oriented graph with vertices reflecting complex systems coordinates (concepts) and edges describing cause-effect relations between the vertices. We consider weighted $\mathrm{CM}$ where edges are weighted depending on significance of corresponding relation.

During complex system operation under different disturbances CM coordinates change in time. Each CM vertex $R_{i}$ is set to values $Y_{i}(k)$ in discrete times $k=0,1,2, \ldots$. The next value $Y_{i}(k+1)$ is determined by current value $Y_{i}(k)$ and coordinates increments of other vertices $R_{j}$ connected to $R_{i}$ at time $k$. Change of vertices $R_{j}$ coordinates $P_{j}(k)=\Delta Y_{j}(k)=Y_{j}(k)-Y_{j}(k-1), k>1$, is called impulse according to $[1,2,3]$. Spreading of impulses over CM vertices is called impulse process and is described by the equation: 


$$
Y_{i}(k+1)=Y_{i}(k)+\sum_{j=1}^{n} a_{i j} P_{j}(k), i=1, \ldots, n,
$$

where $a_{i j}$ is basic weight of edge from $R_{j}$ to $R_{i}$.

Another way, CM vertices coordinates' evolution rule (1) may be formulated as first-order difference equation in increments:

$$
\Delta Y_{i}(k+1)=\sum_{j=1}^{n} a_{i j} \Delta Y_{j}(k), i=1, \ldots, n .
$$

Equation (2) may be written in vector form:

$$
\Delta \bar{Y}(k+1)=A \Delta \bar{Y}(k),
$$

where $A$ is a transposed incidence matrix, $\Delta \bar{Y}$ is a vector of coordinates increments. Models (2), (3) describe multivariate dynamic discrete system in free motion of $\mathrm{CM}$ vertices.

In [4-8] CM impulse process control automation is performed by external control inputs generating based on vertices coordinates varying using known control theory methods. To accomplish this forced motion equation under impulse process was proposed:

$$
\Delta Y_{i}(k+1)=\sum_{j=1}^{n} a_{i j} \Delta Y_{j}(k)+b_{i} \Delta u_{i}(k), i=1, \ldots, n,
$$

where $\Delta u_{i}(k)=u_{i}(k)-u_{i}(k-1)$ is control input increment which is implemented by means of varying resources of vertex $R_{i}$.

Such an approach has a drawback: it may be practically unrealistic to vary $\mathrm{CM}$ vertices resources a lot. The article proposes another approach.

\section{PRoblem DEFINITION}

We consider new principle of control synthesis for CM impulse process. The main idea is to vary CM edges weights $a_{i j}$ to actualize controls $u_{i}(k)$ in closedloop system. It is possible when we may change degree of impact of one CM vertex on another. Decision-maker may implement weights varying by means of changing administrative, scientific, financial, political, educational, informational interrelations between coordinates of complex system described by CM. Control $u_{i}(k)$ is performed not by direct impact on the vertex to be changed on the $k$-th sampling period, but by varying one of the weighting coefficients $a_{i j}$ among edges leading to this vertex. Thus, control $u_{i}(k)$ should be formed not through resources of $Y_{j}(k)$ but through modifying degree of influence $\left(\Delta a_{i j}\right)$ of $Y_{j}(k)$ on $\Delta Y_{i}(k+1)$. This problem is solved in the proposed article.

The purpose of the article is to develop method of CM impulse process 
control based on varying edges' weights.

\section{METHOD OF STABLE CM IMPULSE PROCESSES CONTROL BASED ON WEIGHTS VARYING}

Consider free motion CM impulse process equation (3) not in increments but in full coordinates (in scalar and vector forms):

$$
\begin{gathered}
Y_{i}(k+1)=Y_{i}(k)+\left(1-q^{-1}\right) \sum_{j=1}^{n} a_{i j} Y_{j}(k), \quad i=1, \ldots, n, \\
\bar{Y}(k+1)=\left(I+A-A q^{-1}\right) \bar{Y}(k),
\end{gathered}
$$

where $q^{-1}$ is inverse discrete time shift operator.

If $\lim _{k \rightarrow \infty} \Delta Y_{i}(k)=0$, for stabilization of $\mathrm{CM}$ vertices coordinates $Y_{i}$ at predefined levels $G_{i}$ it is necessary to generate controls influencing CM vertices each sampling period according to designed control law by means of weights $\Delta a_{i j}(k)$ varying.

Suppose that for each $Y_{i}(k+1)$ there is no more than one coefficient $a_{i \mu_{i}}$ that may be varied, and that this additional weight $\Delta a_{i \mu_{i}}(k)$ is applied directly to coordinate $Y_{\mu_{i}}(k)$. Then forced motion equation for controlled impulse process for each CM coordinate $Y_{i}$ will be written as:

$$
Y_{i}(k+1)=Y_{i}(k)+\left(1-q^{-1}\right) \sum_{j=1}^{n} a_{i j} Y_{j}(k)+\Delta a_{i \mu_{i}}(k) Y_{\mu_{i}}(k)+\xi_{i}(k), i=1, \ldots, n,
$$

where $\Delta a_{i \mu_{i}}(k)=a_{i \mu_{i}}(k)-a_{i \mu_{i}}(k-1), \xi_{i}(k)$ is uncontrolled random noise with zero mean.

Based on (5), (6) in vector form forced motion equation of $\mathrm{CM}$ impulse process may be written as:

$$
\bar{Y}(k+1)=\left(I+A-A q^{-1}\right) \bar{Y}(k)+L(k) \Delta \bar{a}(k)+\bar{\xi}(k) .
$$

Matrix $L(k)$ is composed of measured CM coordinates $Y_{\mu_{i}}(k)$ that influence coordinates $Y_{i}(k+1), i=1,2, \ldots, n$, via edges with variable weights $\Delta a_{i \mu_{i}}(k)$ which are in fact controls here. Strict rules for composing weights increments vector $\Delta \bar{a}(k)$ and matrix $L(k)$ in (7) are formulated below.

a) Vector of weights increments $\Delta \bar{a}(k)$ has dimension $m \leq n-$ it includes only non-zero elements $\Delta a_{i \mu_{i}}(k) \neq 0$. If some weight in CM cannot be varied then increment $\Delta a_{i \mu_{i}}(k)=0$ is not included into $\Delta \bar{a}(k)$.

b) Matrix $L(k)$ has dimension $n \times m$ and contains no more than one element in each $i$-th row equal to $Y_{\mu_{i}}$ which affects vertex $Y_{i}$ via weight increment $\Delta a_{i \mu_{i}}$. 
This element's column number is equal to number of element $\Delta a_{i \mu_{i}}$ in $\Delta \bar{a}(k)$. If any vertex $Y_{i}$ does not have any incoming edges that may be varied then all elements of $i$-th row are zero.

Optimal control vector $\Delta \bar{a}(k)$ is designed on the base of the following quadratic optimization criterion:

$$
J(k+1)=E\left\{[\bar{Y}(k+1)-\bar{G}]^{T}[\bar{Y}(k+1)-\bar{G}]+\Delta \bar{a}^{T}(k) R \Delta \bar{a}(k)\right\},
$$

where $\bar{G}$ is reference input vector for CM coordinates vertices stabilizing on predefined levels, $R$ is diagonal positive-definite matrix, $E$ is conditional expectation operator as of time moment $k$.

After differentiating we obtain the following equation of multivariate controller:

$$
\frac{\partial J(k+1)}{\partial \Delta \bar{a}(k)}=2 L^{T}(k)\left[\left(I+A-A q^{-1}\right) \bar{Y}(k)+L(k) \Delta \bar{a}(k)+\bar{\xi}(k)-\bar{G}\right]+2 R \Delta \bar{a}(k)=0,
$$

which leads to the control law:

$$
\Delta \bar{a}(k)=-\left(L^{T}(k) L(k)+R\right)^{-1} L^{T}(k)\left[\left(I+A-A q^{-1}\right) \bar{Y}(k)+\bar{\xi}(k)-\bar{G}\right] .
$$

If $\bar{\xi}(k)$ is not measured, then expression (10) is estimated as:

$$
\Delta \bar{a}(k)=-\left(L^{T}(k) L(k)+R\right)^{-1} L^{T}(k)\left[\left(I+A-A q^{-1}\right) \bar{Y}(k)-\bar{G}\right] .
$$

Based on equations (7), (10) we get the following closed-loop equation for CM impulse process:

$$
\begin{aligned}
& \bar{Y}(k+1)=\left\{I-L(k)\left[L^{T}(k) L(k)+R\right]^{-1} L^{T}(k)\right\}\left(I+A-A q^{-1}\right) \bar{Y}(k)+ \\
& +L(k)\left[L^{T}(k) L(k)+R\right]^{-1} L^{T}(k) \bar{G}+\left\{I-L(k)\left[L^{T}(k) L(k)+R\right]^{-1} L^{T}(k)\right\} \bar{\xi}(k) .
\end{aligned}
$$

Here $L(k)$ is time varying non-linear matrix depending on $\bar{Y}(k)$. Some insights about stability of closed-loop system (11) are given below.

Proposition 1. Let forced motion equation of CM impulse process be described by (7) where $\Delta \bar{a}(k)$ is $m$-dimensional vector of weights and $L(k)$ is $n \times m$ matrix composed of coordinates $Y_{\mu_{l}}(k)$ according to rule (b) $(l=1, . ., m$ are numbers of respective increments in $\Delta \bar{a}(k))$. Then $m \times m$ matrix $L^{T}(k) L(k)$ in control law (10) is diagonal with elements $Y_{\mu_{l}}^{2}(k), l=1, \ldots, m$.

Proof. According to rule (b) matrix $L(k)$ contains $Y_{\mu_{l}}(k)$ in $l$-th column, and all other elements in the column are zero. After transposing, element $Y_{\mu_{l}}(k)$ is in $l$-th row in $L^{T}(k)$. Then after multiplying - in $L^{T}(k) L(k)$ we will get element $Y_{\mu_{l}}^{2}(k)$ in $l$-th row and $l$-th column for all $m$ rows and columns, while all other elements are zero. 
Corollary 1. As far as matrix $R$ in (8) is $m$-dimensional, diagonal and positive-definite, inverse matrix $\left(L^{T}(k) L(k)+R\right)^{-1}$ in (11) is diagonal with elements $\frac{1}{Y_{\mu_{l}}^{2}(k)+R_{l l}}, l=1, \ldots, m$, that are always positive.

Corollary 2. Matrix $B(k)=I-L(k)\left[L^{T}(k) L(k)+R\right]^{-1} L^{T}(k)$ in closed-loop equation (11) is $n \times n$ diagonal matrix with main diagonal elements equal to $1-\frac{Y_{\mu_{l}}^{2}(k)}{Y_{\mu_{l}}^{2}(k)+R_{l l}}=\frac{R_{l l}}{Y_{\mu_{l}}^{2}(k)+R_{l l}}$ in rows that correspond to non-zero rows of $L(k)$ and equal to 1 otherwise. Thus, eigenvalues of $B(k)$ are always $0<\lambda_{i} \leq 1, i=1, \ldots, n$.

It is important that despite being time varying and non-linear with respect to $\bar{Y}(k)$ matrix $B(k)$ is never unstable because its eigenvalues are always positive and less or equal than 1 .

Consider stable CM, i.e. amplitude of eigenvalues of incidence matrix $A$ are less than 1. Closed-loop system (11) is stable if absolute values of roots of its characteristic equation are less than 1 , too. This equation is written as

$$
\operatorname{det}\left(I-B(k)\left(I+A-A q^{-1}\right) q^{-1}\right)=0,
$$

where $B(k)=I-L(k)\left[L^{T}(k) L(k)+R\right]^{-1} L^{T}(k)$.

We already know that $B(k)$ is diagonal matrix with elements in $(0 ; 1]$ interval. If $B(k)$ were identity matrix, system could not be unstable because $I-\left(I+A-A q^{-1}\right) q^{-1}=\left(1-q^{-1}\right)\left(I-A q^{-1}\right)$, and roots of $\operatorname{det}\left(I-A q^{-1}\right)=0$ are eigenvalues of $A$ which is stable. If instead of identity matrix we multiply the same expression by diagonal matrix some elements of which are positive and less than 1 (and some are still equal to 1), it cannot become unstable. For simplicity it will be demonstrated below in case of triangular matrix $A$. In this case determinant in (12) is calculated easily because $\left(I-B(k)\left(I+A-A q^{-1}\right) q^{-1}\right)$ is also triangular matrix, so its determinant equals to product of diagonal elements. Thus, in fact we need to prove only scalar case, i.e., that absolute values of roots of equation

$$
1-b\left(1+a-a q^{-1}\right) q^{-1}=0
$$

are not greater than 1 if $|a|<1,0<b<1$ (for $b=1$ it's obvious).

Let us solve (13) as quadratic equation with respect to $q^{-1}$ :

$$
b a q^{-2}-b(1+a) q^{-1}+1=0 .
$$

If discriminant $D=b^{2}(1+a)^{2}-4 b a<0$ then roots are 
$q_{1,2}^{-1}=\frac{b(1+a) \pm i \sqrt{4 b a-b^{2}(1+a)^{2}}}{2 b a}$, then absolute value is $\left|q_{1,2}^{-1}\right|=\frac{1}{\sqrt{|a b|}}>1$, so $\left|q_{1,2}\right|<1$. If $D \geq 0$, that is possible when $a<0$, then $q_{1,2}^{-1}=\frac{b(1+a) \pm \sqrt{b^{2}(1+a)^{2}-4 a b}}{2 b a}=\frac{1+a}{2 a} \pm \sqrt{\left(\frac{1+a}{2 a}\right)^{2}-\frac{1}{a b}}$. It is easily seen that $q_{1}^{-1}=\frac{1+a}{2 a}+\sqrt{\left(\frac{1+a}{2 a}\right)^{2}-\frac{1}{a b}}$ monotonically increases with $b$ increasing from 0 to 1 , and maximal value is $\frac{1+a+1-a}{2 a}=\frac{1}{a}<-1 ; q_{2}^{-1}=\frac{1+a}{2 a}-\sqrt{\left(\frac{1+a}{2 a}\right)^{2}-\frac{1}{a b}}$ monotonically decreases and minimal value is $\frac{1+a-1+a}{2 a}=1$. Anyway, $\left|q_{1,2}^{-1}\right|>1 \Rightarrow\left|q_{1,2}\right|<1$

\section{STABILISATION OF STUDENT'S SOCIAL-EDUCATIONAL PROCESS VIA COGNITIVE MAP WEIGHTS VARYING}

As an example of application of control law proposed above consider stabilization of CM of a student, specifically, of social-educational process of a student. The following concepts are selected as vertices of this CM:

1. Time spent on study.

2. Success in studies.

3. Time spent on work.

4. Success in work.

5. Money earned.

6. Health (time and finance spent on health care).

7. Family welfare.

8. Hobby (time and money spent on leisure and entertainment).

This CM with basic edge weights set by experts can be seen on fig. 1 .

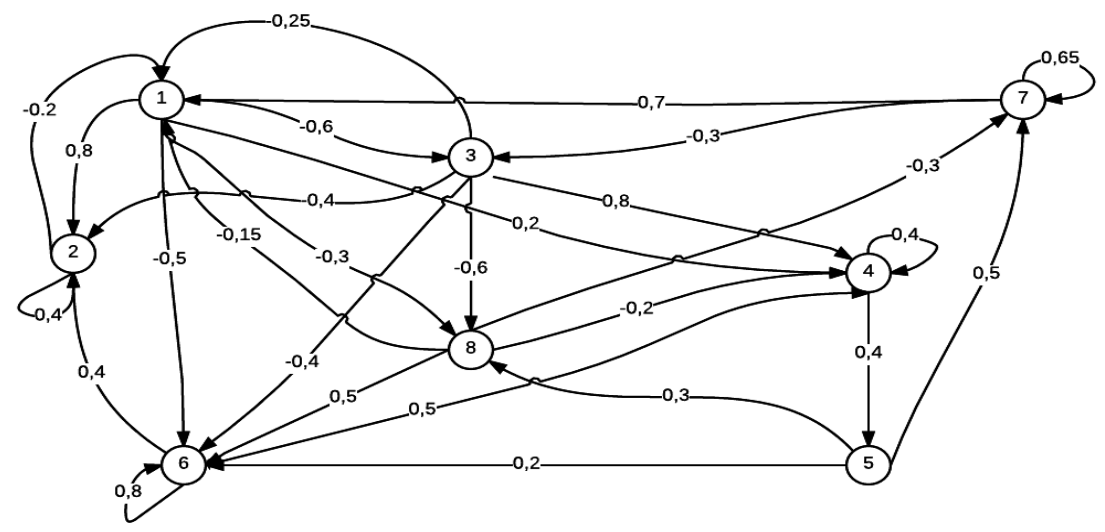

Fig. 1. CM of student

(C) V.D. Romanenko, Y.L. Milyavsky, 2016 
Equation (3) is written in this case as:

$$
\left(\begin{array}{c}
\Delta Y_{1}(k+1) \\
\Delta Y_{2}(k+1) \\
\Delta Y_{3}(k+1) \\
\Delta Y_{4}(k+1) \\
\Delta Y_{5}(k+1) \\
\Delta Y_{6}(k+1) \\
\Delta Y_{7}(k+1) \\
\Delta Y_{8}(k+1)
\end{array}\right)=\left(\begin{array}{cccccccc}
0 & -0.2 & -0.25 & 0 & 0 & 0 & 0,7 & -0.15 \\
0.8 & 0.4 & -0,4 & 0 & 0 & 0.4 & 0 & 0 \\
-0.6 & 0 & 0 & 0 & 0 & 0 & -0.3 & 0 \\
0.2 & 0 & 0,8 & 0.4 & 0 & 0,5 & 0 & -0.3 \\
0 & 0 & 0 & 0.4 & 0 & 0 & 0 & 0 \\
-0.5 & 0 & -0.4 & 0 & 0,2 & 0.8 & 0 & 0.5 \\
0 & 0 & 0 & 0 & 0.5 & 0 & 0.65 & -0.3 \\
-0.3 & 0 & -0.6 & 0 & 0,3 & 0 & 0.4 & 0
\end{array}\right)\left(\begin{array}{l}
\Delta Y_{1}(k) \\
\Delta Y_{2}(k) \\
\Delta Y_{3}(k) \\
\Delta Y_{4}(k) \\
\Delta Y_{5}(k) \\
\Delta Y_{6}(k) \\
\Delta Y_{7}(k) \\
\Delta Y_{8}(k)
\end{array}\right) .
$$

Suppose decision-maker (student) can vary the following weight coefficients:
a) $a_{13}$ - how time spent on work affects time spent on study;
b) $a_{23}$ - how time spent on work affects success in studies;
c) $a_{31}$ - how time spent on study affects time spent on work;
d) $a_{41}$ - how time spent on study affects success in work;
e) $a_{65}$ - how earned money affects health level;
f) $a_{75}$ - how earned money affects family welfare;
g) $a_{83}$ - how time spent on work affects hobby.

So, according to rule (a)

$$
\Delta \bar{a}=\left(\begin{array}{lllllll}
\Delta a_{13} & \Delta a_{23} & \Delta a_{31} & \Delta a_{41} & \Delta a_{65} & \Delta a_{75} & \Delta a_{83}
\end{array}\right)^{T}
$$

and according to rule (b):

$$
L(k)=\left(\begin{array}{ccccccc}
Y_{3}(k) & 0 & 0 & 0 & 0 & 0 & 0 \\
0 & Y_{3}(k) & 0 & 0 & 0 & 0 & 0 \\
0 & 0 & Y_{1}(k) & 0 & 0 & 0 & 0 \\
0 & 0 & 0 & Y_{1}(k) & 0 & 0 & 0 \\
0 & 0 & 0 & 0 & 0 & 0 & 0 \\
0 & 0 & 0 & 0 & Y_{5}(k) & 0 & 0 \\
0 & 0 & 0 & 0 & 0 & Y_{5}(k) & 0 \\
0 & 0 & 0 & 0 & 0 & 0 & Y_{3}(k)
\end{array}\right) .
$$

All eigenvalues of $A$ are less than 1 by absolute value, the system is stable. All vertices coordinates are measured in scale from 0 to 10 and initial values are set to 5 for illustrative purpose. Suppose that initial impulse is negative: success in studies and health decrease from 5 to 4 level. Our goal is to increase success in studies and health up to 6 level. Having applied control law (10) with $R$ equal to identity $7 \times 7$ matrix, we obtain the following impulse process (Fig. 2). 

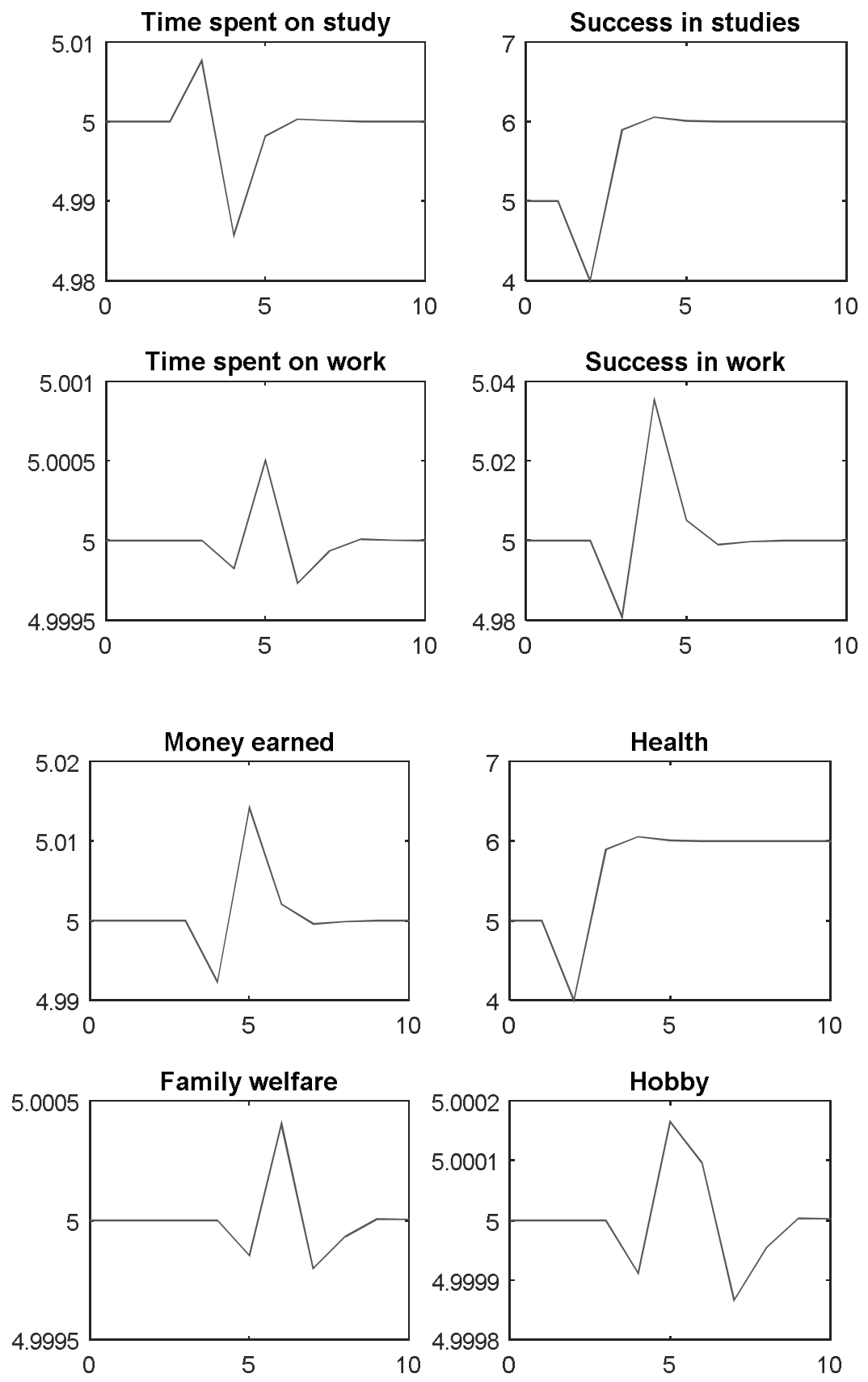

Fig. 2. Controlled impulse process

Weights increments generated by the control law are the following (Fig. 3). 

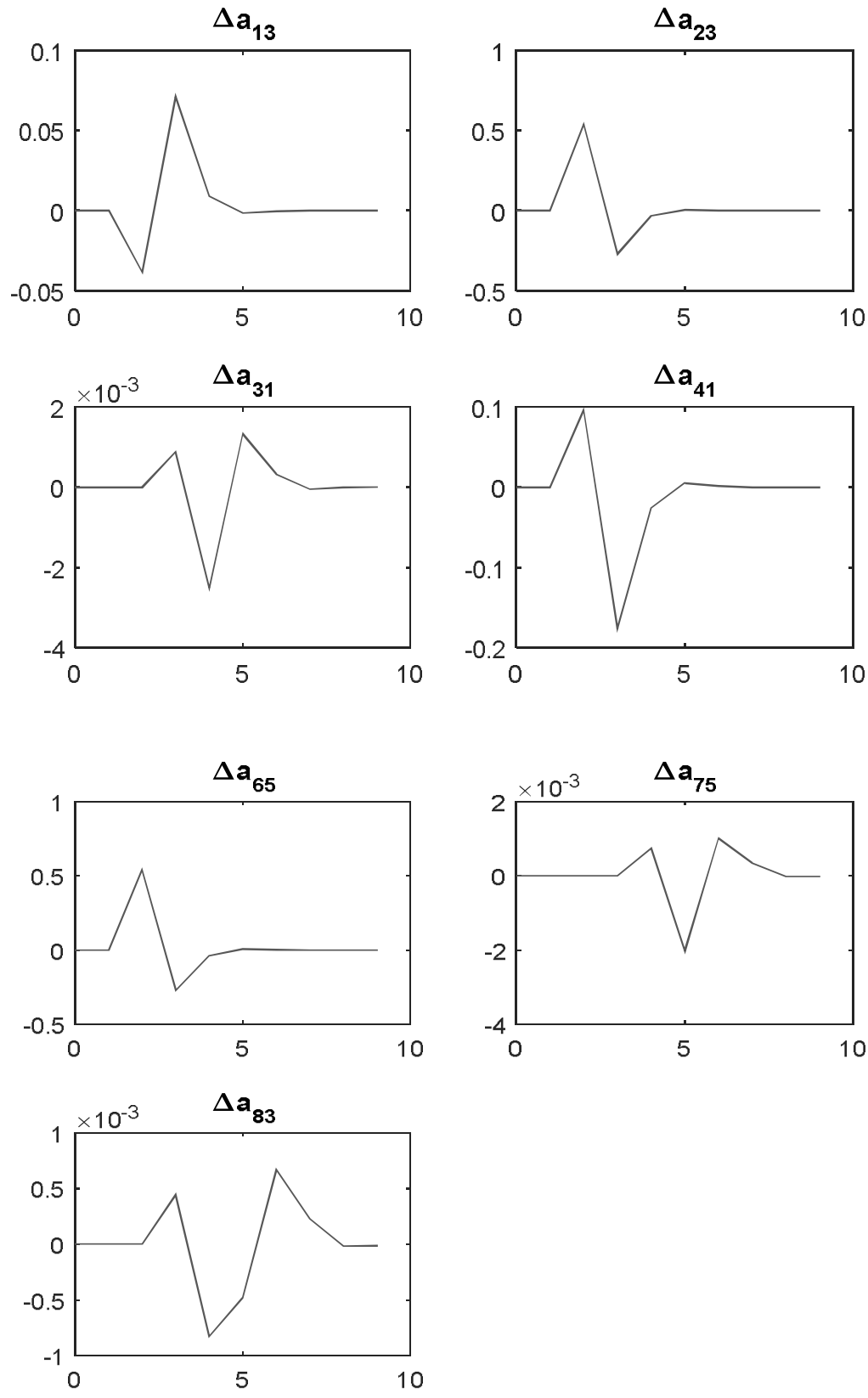

Fig. 3. Weights increments

\section{RESULTS}

As we can see from the simulation results proposed algorithm allows setting $\mathrm{CM}$ vertices coordinates in impulse process at new adjusted levels. Coordinates converge to reference inputs quickly, amplitude is small enough for practical implementation. This is achieved only via selected CM edges weights varying. Range of the weights change is reasonably small, so that decision-maker can 
physically vary them in real life impulse process. Thus, if CM impulse process is stable, using given quadratic criterion and having edges weights that can be varied it is possible to generate control law which moves selected vertices coordinates to any desired values.

\section{CONCLUSiON}

The article considers new control method of impulse process in CM. This method uses $\mathrm{CM}$ edges weights increments as control inputs as opposed to all other methods that require external controls. This makes it possible to change state of dynamic system described by stable $\mathrm{CM}$ without varying resources associated with $\mathrm{CM}$ vertices. Instead the proposed method is based on changing degree of impact of one $\mathrm{CM}$ vertex on another which is more preferable in lots of practical cases. For stabilization quadratic optimality criterion is proposed and explicit formula for optimal control law is derived. Stability of the closed-loop system after applying this law was demonstrated. For illustrative purposes CM of student's socioeducational process was considered. It was shown that by means of the proposed method several vertices coordinates of this CM are easily stabilized on new levels via weights varying. Simulation proved practical applicability of the proposed method.

1. Axelrod R. The Structure of Decision: Cognitive Maps of Political Elites. - Princeton University Press, 1976. — $404 \mathrm{p}$.

2. Roberts F. Discrete Mathematical Models with Applications to Social, Biological, and Environmental Problems. — Englewood Cliffs, Prentice-Hall, 1976. — 559 p.

3. Горелова Г.В., Захарова Е.Н., Радченко С.А. Исследование слабоструктурированных проблем социально-экономических систем. Когнитивный подход. - Ростов-на-Дону: Изд-во РГУ, 2006. — 332 с.

4. Романенко В.Д., Милявский Ю.Л. Обеспечение устойчивости импульсных процессов в когнитивных картах на основе моделей в пространстве состояний // Системні дослідження та інформаційні технології. - 2014. — № 1. - С. 26-42.

5. Романенко В.Д., Милявский Ю.Л., Реутов А.А. Метод адаптивного управления неустойчивыми импульсными процессами в когнитивных картах на основе эталонных моделей // Проблемы управления и информатики. - 2015. - № 2. - С. 35-45.

6. Романенко В.Д., Милявский Ю.Л. Управление соотношениями координат когнитивной модели сложной системы при неустойчивом импульсном процессе // Системні дослідження та інформаційні технології. - 2015. — № 1. - С. 121-129.

7. Романенко В.Д., Милявский Ю.Л. Стабилизация импульсных процессов в когнитивных картах сложных систем на основе модальных регуляторов состояния // Кибернетика и вычислительная техника. - 2015. - Вып. 179. - С. 43-55.

8. Романенко В.Д., Милявский Ю.Л. Адаптивное координирующее управление соотношениями координат вершин взаимодействующих когнитивных карт в режиме импульсных процессов // Системні дослідження та інформаційні технології. - 2015. - № 3. - С. 109-120. 
UDC 681.5

\title{
CONTROL METHOD IN COGNITIVE MAPS BASED ON WEIGHTS INCREMENTS
}

\author{
V.D. Romanenko, Y.L. Milyavsky \\ Educational and Scientific Complex "Institute for Applied Systems Analysis" \\ of National Technical University of Ukraine "Kyiv Polytechnic Institute"
}

Introduction. Cognitive maps are widely used for modeling large multidimensional systems. These are weighted oriented graphs that represent concepts and relations between them. When external or internal disturbances affect the system impulse process is initiated. It is described by first-order equation in increments of vertices coordinates. A number of articles solved a problem of control in cognitive map's impulse process by means of control theory methods. But all of them used external control inputs, i.e. resources of the vertices, for this purpose.

The purpose of the article is to develop new method of control where cognitive map's edges weights are used as controls for impulse process stabilisation.

Results. New method of control of cognitive maps was developed. It is based on varying of the map's edges weights. It was supposed that some of the vertices may affect other ones in different way, i.e. stronger or weaker. After presenting impulse process model in full coordinates weights increments were added to the difference equation. They were considered as control inputs which were generated according to the control law developed based on quadratic criterion. Stability of the closed-loop system was demonstrated. To verify the results, method was simulated using cognitive map of student's socio-educational process. Finally we obtained that for stable cognitive map vertices' coordinates are quickly stabilised at new levels via edges' weights varying.

Conclusion. Applying the proposed method of control based on weights varying to impulse process of cognitive map allows setting vertices coordinates on desired levels.

Keywords: cognitive map, control law, weights increments, stabilisation at new levels.

1. Axelrod R. The Structure of Decision: Cognitive Maps of Political Elites. Princeton University Press. 1976. - 404 p.

2. Roberts F. Discrete Mathematical Models with Applications to Social, Biological, and Environmental Problems. — Englewood Cliffs, Prentice-Hall, 1976. — 559 p.

3. Gorelova G.V., Zakharova E.N., Radchenko S.A. Research of semi-structured problems in socio-economic systems. Cognitive approach. - Rostov-na-Donu: Publisher RSU, 2006. - 332 p. (in Russian).

4. Romanenko V.D., Milyavskiy Y.L. Stabilizing of impulse processes in cognitive maps based on state-space models // System Research \& Information Technologies. 2014. — №1. - P. 26-42 (in Russian).

5. Romanenko V.D., Milyavskiy Y.L., Reutov A.A. Adaptive Control Method for Unstable Impulse Processes in Cognitive Maps Based on Reference Models // Journal of Automation and Information Sciences. — 2015. — № 2. - P. 35-45 (in Russian).

6. Romanenko V.D., Milyavskiy Y.L. Coordinates ratio control for cognitive model of a 
complex system under unstable impulse process // System Research \& Information Technologies. — 2015. - №1. - P. 121-129 (in Russian).

7. Romanenko V.D., Milyavskiy Y.L. Impulse processes stabilisation in cognitive maps of complex systems based on modal state controllers // Cybernetics and Computer Science. - 2015. — №179. - P. 43-55 (in Russian).

8. Romanenko V.D., Milyavskiy Y.L. Adaptive coordinating control of interacting cognitive maps vertices' ratios in impulse mode // System Research \& Information Technologies. — 2015. — №3. - P. 109-120 (in Russian).

Получено 24.03.2016 